\title{
Underwater endoscopic submucosal dissection of an obstructing giant colonic lipoma
}

Gastrointestinal (GI) lipomas are rare $(0.2 \%-4.4 \%$ of benign Gl subepithelial tumors) and usually asymptomatic. Giant colonic lipomas (> $4 \mathrm{~cm}$ ) may cause symptoms such as bleeding or intestinal occlusion and surgical resection is considered the treatment of choice $[1,2]$. With the development of endoscopic submucosal dissection (ESD), we have been able to resect larger tumors. We report a case of a large colonic lipoma treated by ESD.

A 63-year-old Caucasian woman was admitted in our Emergency Department for symptoms of subocclusion. A computed tomography (CT) scan of her abdomen showed a large mass located in the left colon ( $\mathbf{F i g} . \mathbf{1}$ ). Endoscopic examination confirmed this to be a soft yellowish submucosal tumor, with a short and wide pedicle, in the distal sigmoid colon. The pedicle was partially overlaid by hyperplastic mucosa, probably as a result of the repair of tissue damage from traction and twisting of the limited peduncle due to peristalsis.

We decided to resect the lesion using underwater ESD. The technical aspects of our endoscopic procedure were as follows. The first step was to ensure there was an adequate submucosal cushion using a mixture of Voluven as the fluid solution, along with a small amount of indigo carmine and epinephrine. The next step was to incise the mucosa around the pedicle and dissect the submucosal tissue under the lipoma from the anal side. This was done using an IT knife and a DualKnife nano (both Olympus), and an ST Hood short type (Fujifilm) was attached to the tip of the scope during the procedure.

After a procedure lasting 2 hours, an en bloc resection was obtained and the giant lipoma was removed from the colon with a foreign body forceps ( $\triangleright$ Video 1 ). The

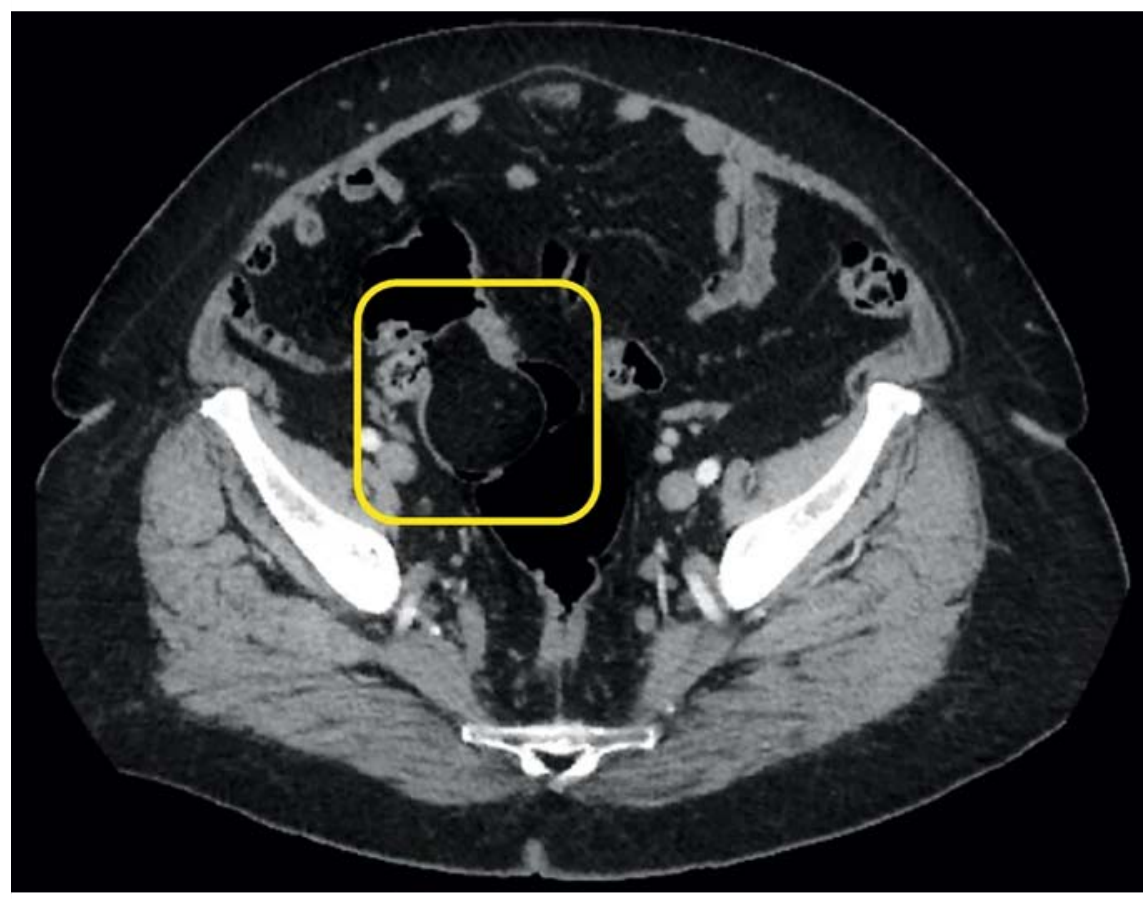

- Fig. 1 Computed tomography scan image showing a mass located in the left colon.

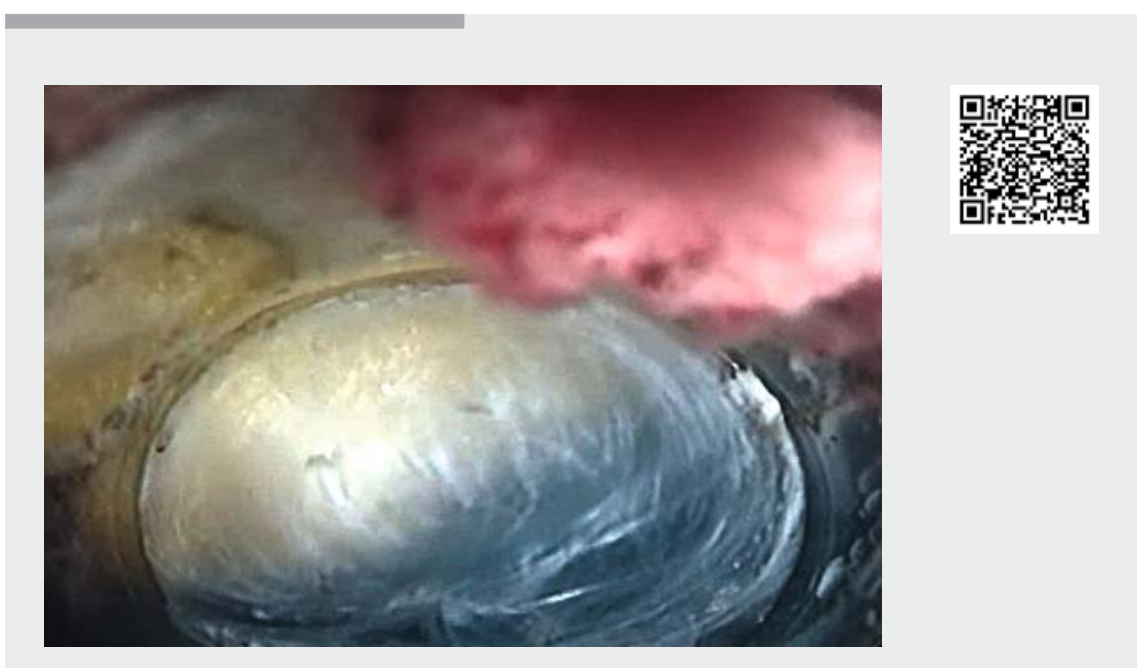

$\checkmark$ Video 1 A large submucosal tumor in the sigmoid colon that was resected by underwater endoscopic submucosal resection. 
specimen was $8 \mathrm{~cm} \times 5 \mathrm{~cm}$ in size. No minor or major complications occurred and the patient was discharged after 2 days of clinical observation. Histologic analysis confirmed the diagnosis of a lipoma.

To the best of our knowledge, this clinical case represents the first large symptomatic sigmoid colon lipoma treated by ESD to be reported in the literature. ESD, which requires a highly experienced operator, could be a safe alternative to surgical resection in selected cases when giant lipomas are complicated by intussusception or bowel obstruction.

Endoscopy_UCTN_Code_TTT_1AQ_2AD

Competing interests

None
The authors

Angelo Caruso ${ }^{1}$, Costantino Sgamato ${ }^{2}$, Helga Bertani $^{1}$, Flavia Pigò ${ }^{1}$, Santi Mangiafico ${ }^{1}$, Giuseppe Grande ${ }^{1}$, Rita Luisa Conigliaro ${ }^{1}$

1 Digestive Endoscopy Unit, Ospedale Civile di Baggiovara, Azienda OspedalieroUniversitaria di Modena, Baggiovara, Italy

2 Gastroenterology Unit, Department of Clinical Medicine and Surgery, University of Naples Federico II, Naples, Italy

\section{Corresponding author}

\section{Angelo Caruso, MD}

Ospedale Civile di Baggiovara, Digestive Endoscopy Unit, Via Giardini 1355, 41126 Baggiovara, Modena, Italy angelocaruso@hotmail.it

\section{References}

[1] Lorenzo D, Gonzalez JM, Benezech A et al. Endoscopic resection of giant GI lipoma: a case series. VideoGIE 2016; 1: 43-46

[2] Nallamothu G, Adler DG. Large colonic lipomas. Gastroenterol Hepatol 2011; 7: 490 492
Bibliography

DOI https://doi.org/10.1055/a-1011-3617

Published online: 27.9.2019

Endoscopy 2020; 52: E90-E91

(c) Georg Thieme Verlag KG

Stuttgart · New York

ISSN 0013-726X

\section{ENDOSCOPY E-VIDEOS}

https://eref.thieme.de/e-videos

Endoscopy E-Videos is a free

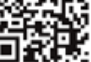
access online section, reporting on interesting cases and new

techniques in gastroenterological endoscopy. All papers include a high quality video and all contributions are freely accessible online.

This section has its own submission website at

https://mc.manuscriptcentral.com/e-videos 